\title{
Virgin queen execution in the stingless bee Melipona beecheii: The sign stimulus for worker attacks*
}

\author{
Stefan JARAU ${ }^{1}$, Johan W. VAN VEEN ${ }^{2}$, Ingrid AGUILAR ${ }^{2}$, Manfred AYASSE ${ }^{1}$ \\ ${ }^{1}$ Institute for Experimental Ecology, University of Ulm, Albert-Einstein-Allee 11, 89081 Ulm, Germany \\ ${ }^{2}$ Center for Tropical Bee Research (CINAT), National University of Costa Rica, PO Box 475-3000, Heredia, \\ Costa Rica
}

Received 5 June 2008 - Revised 22 December 2008 - Accepted 21 January 2009

\begin{abstract}
Stingless bees produce considerable numbers of virgin queens over the year, most of which are superfluous and get executed by the workers. Nothing is known yet about the sign stimulus that releases the worker attacks. In the present study we investigated the queen execution process in Melipona beecheii and found in both behavioral observations and experiments with caged living virgin queens that workers are not attracted to them from a distance by means of volatile chemicals. Furthermore, worker aggression, which is obvious towards virgin queens that run through the nest excitedly with their abdomen enlarged and the wings beating, was lowered to almost zero when we made the queens "behavior-less" by experimentally killing them. Our results clearly show that the sign stimulus for releasing the execution behavior in Melipona beecheii workers is not a chemical stimulus but the virgin queens' conspicuous behavior, which, we hypothesize, could act as a direct measure of their fitness.
\end{abstract}

stingless bee / Melipona beecheii / virgin queen execution / queen behavior / worker attacks

\section{INTRODUCTION}

One hallmark of eusocial insect societies is the reproductive division of labor (Wilson, 1971). In nests of the advanced eusocial honey bees (Apidae, Apini) and stingless bees (Apidae, Meliponini) two morphologically distinct female castes are always present (Michener, 1974). These are the queens that lay (almost) all fertile eggs and the workers, which in some species can produce fertile eggs from which males develop but never directly produce female offspring. A crucial condition for the functioning and endurance of a colony, therefore, is the continuous presence of a fertile physogastric queen that lays a sufficient amount of eggs to produce at least all of the nest's worker- and queen progeny.

Corresponding author: S. Jarau, stefan.jarau@uni-ulm.de

* Manuscript editor: Yves Le Conte
Honey bees usually produce new queens only when a daughter colony is to be split off the mother colony and in the case of accidental loss or replacement of an old queen (Michener, 1974). Honey bee workers can easily decide when to rear a queen, because they constantly feed the developing larvae and therefore can provide young larvae with special food, known as "royal jelly", that triggers queen development whenever needed (Engels and Imperatriz-Fonseca, 1990; Kucharski et al., 2008). By contrast, stingless bees mass provision their brood cells and close them after the queen's oviposition (Michener, 1974). There is no direct contact between the workers and the developing larvae, which renders an emergency queen rearing as in honey bees difficult. The only known cases where emergency queens are produced in stingless bees are Trigona (Frieseomelitta) varia, Trigonisca (Leurotrigona) muelleri, and Trigonisca (Celetrigona) longicornis, where workers can 
provide larvae with extra food deposited in auxiliary cells (Faustino et al., 2002). In general, however, stingless bees produce excess virgin queens year round, probably in order to prevent a queenless situation (Michener, 1974; Sakagami, 1982). In most taxa queens are reared in royal cells that are larger than worker cells and contain a larger amount of larval food. Therefore, castes are likely determined trophically, with larvae receiving a larger amount of food developing into queens (Sakagami, 1982). In Melipona, however, queens develop in normal sized cells within the brood comb, just as workers and males do. The mechanism of caste determination in Melipona is not clear, and hypotheses range from a genetic determination, probably influenced by environmental and nutritional factors (e.g., Kerr, 1948, 1950, 1969, 1974), to the assumption that individuals completely control their own caste fate, and thus can selfishly develop into queens (e.g., Bourke and Ratnieks, 1999; Ratnieks, 2001; Wenseleers et al., 2003) (see also review by Hartfelder et al., 2006). Regardless of the mode of caste determination the fate of virgin queens in queen right, non-swarming stingless bee colonies is the same - the workers execute them some time after their emergence (Engels and Imperatriz-Fonseca, 1990; Imperatriz-Fonseca and Zucchi, 1995). This process is particularly conspicuous in Melipona, where the number of emerging queens is very high, usually being several percent of the female progeny (Kerr, 1948, 1950, 1969; Kerr and Nielsen, 1966; Kerr et al., 1966; Darchen and Delage-Darchen, 1975; Koedam, 1999; van Veen, 2000; Moo-Valle et al., 2001, 2004; Sommeijer et al., 2003a; Wenseleers et al., 2004; Morais et al., 2006; Santos-Filho et al., 2006). Furthermore, Melipona excess virgin queens are killed within a few hours or days following their emergence from the brood cells (Kerr et al., 1962; Sakagami and Oniki, 1963; Sakagami et al., 1965; Silva et al., 1972; Kleinert and Imperatriz-Fonseca, 1994; Koedam et al., 1995; van Veen et al., 1999; Wenseleers et al., 2004). Sommeijer et al. $(2003 b, c)$ proposed an interesting alternative explanation for the large number of virgin queens produced in Melipona based ontheir observations (i) that many virgin queens of $M$. favosa escaped the worker aggression by leaving the nest and (ii) that some virgin queens succeeded in entering other nests of the same species. The authors hypothesized that worker inclusive fitness could be increased by the departure of non-accepted virgin queens when they reproduce outside their maternal nest. Whether these queens actually can take over foreign nests and reproduce in them, however, remains to be demonstrated.

In $M$. beecheii, virgin queens are active immediately after emerging from the brood cell, and they try to avoid worker aggression by running to the nest's periphery where they hide (van Veen et al., 1999; Moo-Valle et al., 2004). The same behavior was observed in $M$. quadrifasciata anthidioides (Silva et al., 1972) and M. marginata (Kleinert and ImperatrizFonseca, 1994). Once a virgin queen starts to run over the brood combs with her abdomen inflated and her wings vibrating, which likely is related to her attempt to become accepted as a new queen, workers attack and try to kill her (Sakagami and Oniki, 1963; Silva et al., 1972; Koedam et al., 1995; van Veen et al., 1999; Wenseleers et al., 2004; Kleinert, 2005). Despite the many behavioral observations of the queen execution process in stingless bees, nothing is known about how workers distinguish virgin queens from workers, or about the stimuli exhibited by virgin queens that trigger the attacks against them, respectively. Queen production, i.e. the process by which new queens are reared and chosen from among the available gynes, is undoubtedly a target of natural selection, because queens are of great importance to the inclusive fitness of all colony members (Tarpy and Gilley, 2004). In order to understand the mechanism by which a new queen is selected by a group of workers during the queen elimination stage of queen production (Tarpy and Gilley, 2004), however, one has to know the proximate mechanism by which the virgin queens are recognized or which triggers the aggression towards them. Ultimately, the determination of the trigger for the aggressive worker behavior may lead to an understanding of the evolution of virgin queen life history and help to understand why 
Melipona colonies produce such large numbers of virgins.

Many recognition systems in solitary and social insects, including the recognition of dominance status and possibly caste in eusocial species, are mediated by differences in the odor compound composition on the cuticle surfaces of different individuals (e.g., Howard and Blomquist, 1982, 2005; Singer, 1998; Monnin, 2005; Sramkova et al., 2008). Differences in the composition of volatile constituents of virgin and mated females have been shown in several social bee species through chemical analysis as well as by means of behavioral experiments (Ayasse et al., 2001). The few studies in which the cuticular hydrocarbon pattern on the body surface of Melipona bees was investigated all revealed distinct differences in the composition of the detected compounds between individuals of the different sexes and/or castes (M. bicolor: Abdalla et al., 2003; M. scutellaris: Kerr et al., 2004; M. beecheii: Jarau et al., 2006). The different cuticular hydrocarbon compositions of workers and virgin queens therefore could potentially be used by the bees to distinguish between them, and/or contain the stimulus that releases aggression towards the virgin queens. In the present study we investigated the potential role that both olfactory cues and the behavior of young virgin queens of Melipona beecheii could play in releasing worker attacks and queen execution behavior.

\section{MATERIALS AND METHODS}

\subsection{Study site and bee colonies}

The experiments were carried out in March and April 2007 at the Centro de Investigaciones Apícolas Tropicales (CINAT; $9^{\circ} 58^{\prime} 22^{\prime}, \mathrm{N}$, $84^{\circ} 07^{\prime} 45^{\prime}, \mathrm{W}$ ) of the National University in Heredia, Costa Rica. We used 2 colonies (A and B) of Melipona beecheii BENNETT, 1831 (Hymenoptera, Apidae, Meliponini) that were collected in the Province of Guanacaste (north-western Costa Rica) and kept at the University Campus in wooden boxes inside a darkened room under red light conditions. The nests were connected to the outside via plastic tubes to allow free foraging. From each of the two colonies we separated 4 small boxes $(12 \times 11 \times 4 \mathrm{~cm}$ inner space) containing one brood comb with approximately 200 cells and 25-30 adult worker bees. The boxes were covered with glass sheets in order to allow observations of the bees' behavior and to register the emergence of virgin queens. All experiments described below were carried out in these observation boxes, filmed under red light with a video camera (Panasonic NV-GS 200 EG-S DV), and the respective analyses were done from the video tapes.

\subsection{Behavioral observations}

We occasionally filmed the behavior of virgin queens and workers in our observation boxes during periods when no experiments were conducted. In addition, we made direct observations and took notes of the bees' behavior and interactions. The aim of these observations (in sum ca. $130 \mathrm{~min}$ ), which were carried out in sequences involving 15 virgin queens, was to describe the normal, unrestrained behavior of virgin queens and workers in order to compare it with the behavior during the experimental treatments, i.e. during the cage experiments and virgin queen bioassays (see below).

\subsection{Cage experiments}

To find out whether workers are attracted to virgin queens by olfactory cues from a distance and whether aggressive behavior towards them is released without intensive direct contact we conduced experiments with living virgin queens that were put in cages and placed on the brood combs. The cages (Fig. 1) were cylindrical tubes, $4 \mathrm{~cm}$ long and $1.3 \mathrm{~cm}$ in diameter, made of wire netting (mesh size $1 \times 2 \mathrm{~mm}$ ). The size of the cages allowed the bees to freely move inside them, and the wire netting allowed direct antennal contact between individuals located inside and outside a cage. For the experiments we only used virgins that were attacked by workers directly before caging them in order to be sure that the respective individuals produced all stimuli necessary to release aggression in worker bees. As controls we tested cages containing a randomly chosen worker and empty cages, respectively. We conducted 12 experiments, each consisting of a series of all 3 cage treatments (virgin: V; worker: W; empty: E). The treatments were presented to the workers in differing orders (V-W-E, V-E-W, W-V-E, W-E-V, E-W-V, E-V-W; two times each) and in a randomized sequence. Six experiments were carried out in observation boxes derived 


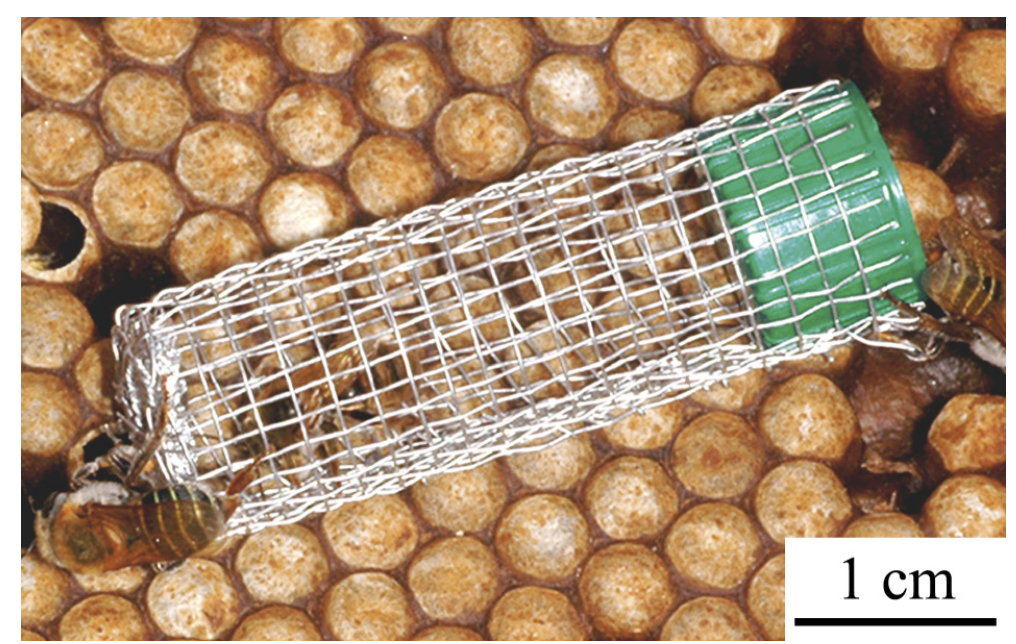

Figure 1. Wire netting tube used for the cage experiments. In the example shown a virgin queen can be seen inside the left part of the cage.

from nest A, and 6 in boxes derived from nest B. After the introduction of a cage we allowed the colony to settle from any disturbance that might have been caused by opening the box, for $5 \mathrm{~min}$ before we filmed the cage for another $5 \mathrm{~min}$. From the video tapes we counted the number of worker contacts with a cage and measured their durations.

\subsection{Virgin queen bioassays}

To find out whether the lively running of virgin queens - and/or vibrations or sounds they likely produce at the same time - triggers the worker attacks, we carried out bioassays with living and experimentally killed virgins. To this end we filmed a virgin queen for ten minutes while she was running around in the observation box, then took her out in a clean, airtight vial (Supelco ${ }^{\circledR} 2 \mathrm{~mL}$, solid cap PTFE liner) and killed her by freezing at $-82^{\circ} \mathrm{C}$ for $2 \mathrm{~min}$. Subsequently, we allowed the dead body to reach ambient temperature for another $2 \mathrm{~min}$, and then placed it on top of the brood comb in the same box the individual was previously taken from. We assume that the bees' odor bouquets were not altered during the short time we kept them in an airtight vial. After returning a virgin queen to the observation box we filmed her for another $10 \mathrm{~min}$. We carried out 4 bioassays with virgins taken from observation boxes derived from nest $A$, and 5 with virgins taken from boxes derived from nest $\mathrm{B}$. As a control we randomly chose 9 workers ( 5 from the A-boxes,
4 from the B-boxes), sacrificed them in the same way as the queens, put them back on the comb, and filmed them for $10 \mathrm{~min}$. From the video tapes we determined the numbers and durations of worker contacts towards living and dead virgin queens and towards dead workers, respectively.

\subsection{Statistical analyses}

Because of small sample sizes and non-normal distributions for some of the data we applied nonparametric procedures for the statistical tests using SigmaStat (Version 3.5; Systat Software). Data from experiments carried out in the observation boxes derived from nest A and B were pooled, because colony origin did not influence the contact numbers and times shown by the workers (MannWhitney tests, no differences between experiments done within the A- and B-boxes, respectively). For the comparison of the number and duration of worker contacts towards cages containing virgin queens and workers or towards empty cages, respectively, we carried out Kruskal-Wallis tests. To test whether killing virgin queens by freezing has a significant effect on the workers aggressive behavior towards them we conducted a Wilcoxon signedranks test for repeated measures. The numbers of aggressive contacts towards dead virgin queens and towards dead workers were compared with a MannWhitney test. In order to account for the double use of the data for the aggressive contacts towards 
dead virgin queens (comparisons vs. living virgins and vs. dead workers) we adjusted the $P$-values according to the Bonferroni method $\left(P_{\text {adjusted }}=\right.$ $\left.P_{\text {calculated }} \times 2\right)$. The durations of worker contacts towards dead virgin queens and dead workers were compared with a Mann-Whitney test.

\section{RESULTS}

\subsection{Behavioral observations}

Virgin queens $(\mathrm{N}=12)$ that were sitting motionless on the comb or moved very slowly over it were never attacked by the workers, which apparently were not attracted to them from a distance. Likewise, workers that occasionally passed by and touched an inactive virgin queen either shortly antennated her, normally went on, or carried her away (probably to the waist dump). Aggressiveness was only observed towards virgins that actively ran around inside the observation boxes, mainly on top of the brood comb, with an enlarged abdomen and the wings rhythmically beating. Active virgin queens also frequently rubbed their hind legs over the abdomen and often rapidly turned clockwise and counterclockwise in circles. The workers primarily attacked such queens at the abdomen where they tried to grasp them with their mandibles (Fig. 2a), but slipped down rather than biting them. From 107 analyzed attacks against 10 virgin queens, $102(=95.3 \%)$ were directed towards the abdominal region (92 from behind, 10 from the side) and five $(=4.7 \%)$ towards the thorax. Workers never directly attacked a virgin queen at her head. When queens were heavily attacked they often left the brood comb and tried to hide under it or behind a storage pot, or probably tried to escape the worker aggression by leaving the nest. Due to the limited space within our observation boxes and the lack of an exit the queens could not escape, however, and finally were held by up to five workers (mean $\pm 1 \mathrm{SD}: 2.4 \pm 1.2 ; N=11$ ), which clamped the mandibles on their legs, wings or antennae in order to immobilize them (Fig 2b). Importantly, we never observed a worker to behave in the same way as active virgin queens do, neither did any worker in our observation boxes attack other workers.

\subsection{Cage experiments}

Five minutes after the introduction of a cage onto the brood comb the worker bees in the observation boxes showed the same behavior as before the introduction. They calmly walked around in the box and on top of the comb. The bees also occasionally crawled over or sat on the cage, but we never observed bees biting the wire netting. Also, there was no apparent attraction or aggression towards cages that contained a virgin queen. The median (25th/75th percentiles) number of workers contacting queen cages was $8.0(2.5 / 9.5)$, whereas $5.5(2.0 / 9.0)$ and $6.5(2.5 / 14.5)$ workers contacted worker- and empty cages, respectively (Fig. 3a). The slight differences are not statistically significant (Kruskal-Wallis test, $\left.H_{2,34}=0.606, P=0.739\right)$. Likewise, the duration of worker contacts did not differ significantly between empty cages and cages that contained virgin queens or workers (KruskalWallis test, $\left.H_{2,261}=1.627, P=0.443\right)$. Workers remained $7.1(4.1 / 10.5) \mathrm{s}$ on queen cages, $6.7(3.8 / 12.5) \mathrm{s}$ on worker cages, and 5.4 (4.2/9.1) s on empty cages (Fig. 3b).

\subsection{Virgin queen bioassays}

During the 10 minutes filming of the living queens they actively run around within the observation boxes and frequently received aggressive worker attacks as described above. The number of such attacks significantly decreased from $15.0(9.0 / 23)$ to $0.0(0.0 / 5.0)$ after a virgin queen was killed by freezing and subsequently put back onto the brood comb (Wilcoxon signed-ranks test, $Z=-2.666$, $N=9, P=0.004, P_{\text {adjusted }}=0.008$; Fig. 4). There was, however, no significant difference in the number of worker contacts towards dead virgin queens $[0.0(0.0 / 5.0)]$ and dead worker bees [3.0 (1.0/3.25)] (Mann-Whitney test, $T=$ $78.5, \mathrm{~N}_{1}=\mathrm{N}_{2}=9, P=0.556, P_{\text {ad justed }}=1.0$; Fig. 4). In addition, workers did not aggressively attack the dead individuals, but rather grabbed a leg, wing, or antenna, and carried them around or pulled them towards the periphery of the observation boxes. Also, the duration of these contacts did not differ between 

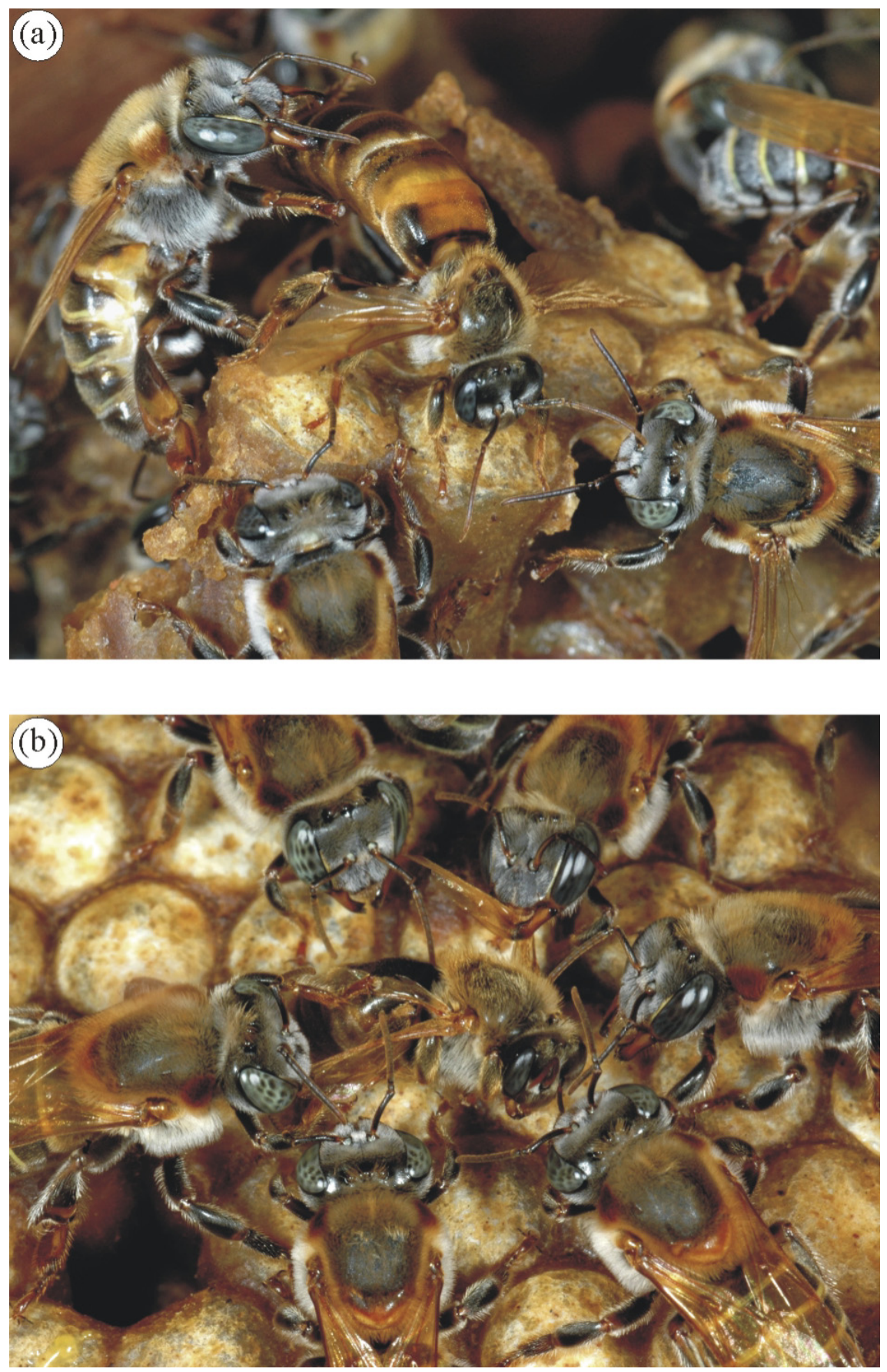

Figure 2. Virgin queen execution in Melipona beecheii. A worker tries to grasp the queen with her opened mandibles (a) while she is lively running through the nest, flapping her wings and presenting her enlarged abdomen. Once several workers have grabbed the queen (b, center) they hold her on the wings, legs, and antennae in order to kill her. 

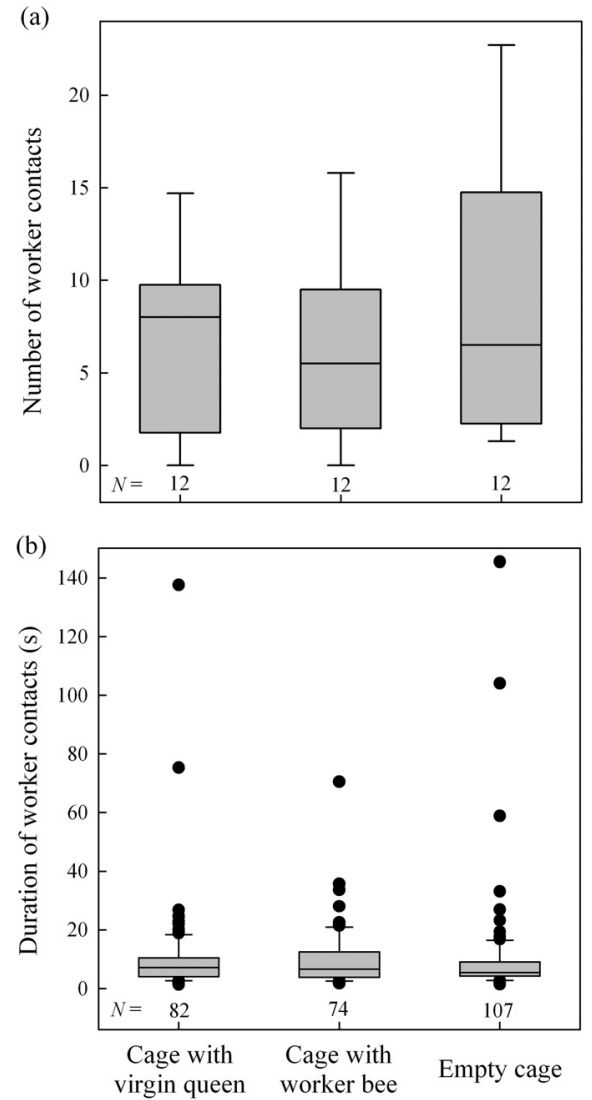

Figure 3. Box and whisker plots of the number of worker contacts (a) and their duration (b) towards cages that contain a virgin queen or a worker bee and towards empty cages. Boxes include the median and the 25th and 75th percentiles; whiskers give the fifth and 95th percentiles; dots represent outlying values; $N$ denotes the numbers of experiments (a) or of worker contacts (b), respectively; total observation time $=180 \mathrm{~min}(60 \mathrm{~min} /$ cage treatment $)$. There are no significant differences in the workers' behavior towards the differently treated cages (Kruskal-Wallis tests; a: $P=0.739$; b: $P=0.443$ ).

dead virgin queens [13.1 (6.0/24.8) s] and dead workers [9.0 (3.9/38.6) s] (Mann-Whitney test, $\left.T=448.0, N_{1}=21, N_{2}=24, P=0.433\right)$.

\section{DISCUSSION}

The behavior of young virgin queens and of the workers involved in executing them ob-

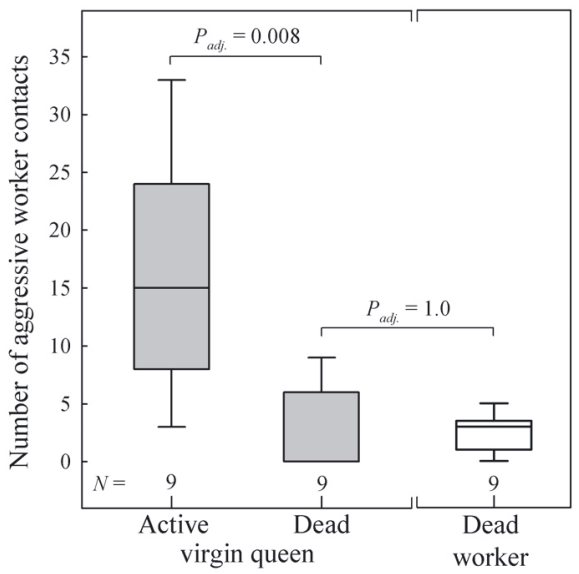

Figure 4. Box and whisker plots of the number of aggressive worker contacts towards active and dead virgin queens and towards dead worker bees. Boxes include the median and the 25th and 75th percentiles; whiskers give the fifth and 95th percentiles; $N$ denotes the numbers of experiments; total observation time $=270 \mathrm{~min}$ (90 min/group). The number of contacts significantly differed when workers were confronted with active and dead virgins (Wilcoxon signed-ranks test), but not when dead virgins or dead workers were presented (Mann-Whitney test). The given $P$ values are adjusted according to the Bonferroni method.

served in the present study is in accordance with that described earlier for M. beecheii (van Veen et al., 1999; Wenseleers et al., 2004) and for other Melipona species (M. compressipes: Sakagami and Oniki, 1963; M. quadrifasciata: Sakagami et al., 1965; Silva et al., 1972; M. marginata: Kleinert and Imperatriz-Fonseca, 1994; Kleinert, 2005; M. favosa: Koedam et al., 1995). The finding that workers mainly attack the abdomen of virgin queens (ca. 95\% of the analyzed attacks in our study) might suggest that queen specific chemical compounds on the cuticle surface trigger the workers' aggressive behavior. This conjecture seems to be supported by the fact that stingless bee queens have a variety of abdominal exocrine glands that are lacking in workers (e.g., Guerino and Oliveira, 2002; Cruz-Landim et al., 2006) and by the known differences in the profiles of $\mathrm{cu}$ ticular hydrocarbons, with chain length of 23- 
29 carbon atoms, between queens and workers (Abdalla et al., 2003; Kerr et al., 2004; Jarau et al., 2006). However, the virgins' rapid spinning movements, which lead to a more frequent presentation of the abdomen to the surrounding workers as compared to other body parts, could also account for the predominance of attacks towards it. In fact, it looks very much as if virgin queens try to turn the abdomen towards any attacking worker, probably because these do not succeed in biting into it. Our cage experiments and the lack of worker aggression towards the freshly killed queens during the bioassays clearly demonstrate that chemicals of lower volatility per se neither attract workers to virgin queens from a distance nor trigger aggressive behavior or attacks after antennal contact with their bodies. Instead, we hypothesize that the virgins' conspicuous behavior - and/or vibrations or sounds that likely are emitted during the runs - accounts for the workers' aggression towards them. This hypothesis is also corroborated by our observation that living virgin queens that inactively sat on the combs or virgins that were restricted in their movements through confinement in a cage (but that still slowly moved inside) were not attacked by workers. Furthermore, van Veen et al. (1999) reported that virgin queens of $M$. beecheii that reacted to worker aggression with a "feigning death" behavior by quietly lying in the nest with their extremities hold close to the body were not aggressively treated anymore but carried to the waist dump. Importantly, virgin queens that were attacked by workers in our observation boxes and then killed by freezing were similarly treated when we subsequently placed them onto the brood combs in our experiments. Kleinert and ImperatrizFonseca (1994) observed that M. marginata virgin queens that do not actively move around are ignored by the workers, too, although they harrass and try to bite active virgins. These observations along with our finding that worker aggression drops to almost zero after we made previously attacked virgin queens "behaviorless" by experimentally killing them or by just slowing them down by placing them in small cages clearly point to the importance of the agitated running and spinning behav- ior (and probably by simultaneously produced mechanical stimuli) as the sign stimulus that releases worker attacks. An alternative explanation could be that virgin queens emit the chemicals that release aggression in workers only while they are agitatedly running through the nest. Such chemicals would then be absent in the slow moving and dead individuals. If such a signal existed it must be highly volatile in order to immediately vanish as soon as a virgin queen stops her activities. In that case, however, one would expect the workers to be attracted to an active virgin from some distance as well as some general arousal in the nest, which we never saw in our behavioral observations. Only workers that are directly touched by the active virgin queen act aggressively against her. Although the involvement of a volatile chemical signal in triggering the workers' attack can't be entirely excluded based on these observations, it seems unlikely.

The mechanism that triggers virgin queen elimination in Melipona markedly differs from honey bees. In Apis mellifera, where excess virgin queens are not eliminated by workers but in queen-queen duels (Gilley, 2001), Pflugfelder and Koeniger (2003) clearly showed that the stinging behavior, which typically is exhibited by the virgin queens during combats, is released by a chemical stimulus located on the bees' abdominal tergites. The fighting behavior was still released when a virgin queen encountered a dead opponent, and even when she was touching an isolated queen abdomen or just the abdomen's dissected tergites (Pflugfelder and Koeniger, 2003).

The function of queen specific abdominal glands in Melipona remains unknown. Koedam (1995) studied the morphological and physiological development of virgin queens of M. favosa in orphan observation boxes and hypothesized that the enlargement of the abdomen could be linked to the production of pheromones that are spread by the bees' quick turns and agitated movements. A clear demonstration for the actual existence and use of virgin queen pheromones is lacking to this day, however, and our experiments show that such pheromones, if they existed, do not account for the worker aggression, at least in $M$. beecheii. Volatiles produced by the abdominal glands 
could be used by workers to identify a virgin queen by her specific bouquet after her acceptance or they may play a role in the mating biology of Melipona. It is also possible that the glands' secretions are important for the interactions between physogastric queens and workers. To answer these questions future studies should investigate the glands' development and compare their products before and after a virgin queen's acceptance, as well as before and after mating, along with bioassays testing the effect of the glands' secretions from queens of different ages on workers and on males.

\subsection{Conclusions}

From our observations and experiments we conclude that the sign stimulus for worker aggression towards virgin queens during the queen elimination process in Melipona beecheii is their conspicuous behavior (including vibrations and sounds that are likely produced by the running and wing flapping) rather than a specific chemical stimulus. From an evolutionary point of view this indeed makes sense. A virgin queen that is easily detected by workers, and thus quickly eliminated from the colony, can never found a filial nest or replace the mother queen. Such queens will not produce offspring and their genes are removed from the colony's gene pool. Therefore, selection likely favors virgin queens that optimize their chance of survival by staying "invisible" as long as they remain motionless, i.e. individuals that can not be simply detected by chemical cues. So why don't virgins remain motionless all the time? We hypothesize that in order to be accepted as a new queen, a virgin - which is predestined to become reproductive (Koedam et al., 1995) - must become active and try to obtain her dominance position by means of agonistic behavior. It is then that the workers attack and try to kill her. We further hypothesize that this process, in which only individuals that are able to survive the murderous chase for some time are not killed by the workers, may serve to select the fittest virgin queens for the eventual replacement of the mother queen or to found a filial nest. This di- rect measure of a queen's fitness would be an honest signal, because the only way for a virgin to pass over the chasing is to remain quiet, which likely leads to her starvation (Koedam et al., 1995), and therefore to her elimination, too. To entirely understand the motivation of both the virgin queens to try to become accepted and the workers to kill them requires additional, detailed investigations of whether, and if applicable how, the presence and condition of the physogastric queen influences their behavior.

\section{ACKNOWLEDGEMENTS}

We thank Eduardo Herrera and Odier Solís for providing us with the bee nests used for this study. We further acknowledge the financial support of our study by the German Research Foundation (DFG; project JA 1715/1-1). All experiments comply with the current laws of Costa Rica were the work was carried out.

Exécution des jeunes reines chez l'abeille sans aiguillon Melipona beecheii : le stimulus qui déclenche l'attaque des ouvrières.

Melipona beecheii / abeille sans aiguillon / comportement agonistique / comportement de mise à mort / reine vierge / régulation sociale / stimulus olfactif

Zusammenfassung - Die Exekution junger Königinnen bei der stachellosen Biene Melipona beecheii: Der Auslösereiz für die Arbeiterinnenattacken. Die hoch eusozialen stachellosen Bienen (Hymenoptera, Apidae, Meliponini) produzieren eine beträchtliche Anzahl junger Königinnen über das ganze Jahr hinweg (Michener, 1974; Sakagami, 1982). Die Mehrzahl der virginellen Königinnen sind jedoch überflüssig und werden von den $\mathrm{Ar}$ beiterinnen getötet (Engels und Imperatriz-Fonseca, 1990; Imperatriz-Fonseca und Zucchi, 1995). Obwohl das Verhalten der Bienen während der Exekution der Königinnen bereits mehrfach beschrieben wurde, ist über den Auslösereiz, der die Arbeiterinnenattacken verursacht, noch nichts bekannt. In der vorliegenden Studie haben wir deshalb untersucht, ob chemische Stoffe, die von den Königinnen abgegeben werden, und/oder deren auffallendes Verhalten, die Attacken der Arbeiterinnen bzw. das 
Töten der Jungköniginnen bei Melipona beecheii auslösen. Wir haben dazu Experimente in kleinen Beobachtungskästchen, die jeweils eine Brutwabe mit ca. 200 Zellen und 25-30 adulten Arbeiterinnen enthielten, durchgeführt. Jungköniginnen, die regungslos auf der Brutwabe saßen, wurden nie angegriffen. Sobald sie jedoch begannen mit vergrößertem (gestreckten) Abdomen umher zu laufen und mit ihren Flügeln zu schlagen, haben die Arbeiterinnen versucht sie zu packen (Abb. 2a), hauptsächlich am Abdomen (95,3\% der beobachteten Attacken). Sobald eine Arbeiterin es schaffte eine Königin an einem Bein, Flügel oder einer Antenne fest zu halten, haben ihr weitere Arbeiterinnen geholfen sie zu töten (Abb. 2b). Wenn wir attackierte Königinnen daran hinderten im Nest umher zu laufen, indem wir sie in kleine Käfige sperrten (Abb. 1), hat die Aggression der Arbeiterinnen ihnen gegenüber aufgehört. Käfige mit einer Jungköniginnen darin hatten nicht mehr Arbeiterinnen angelockt wie Käfige, die eine Arbeiterin enthielten oder leere Käfige. Auch die Zeit, die Arbeiterinnen auf solchen Käfigen verbrachten, war unabhängig von deren Inhalt (Kruskal-Wallis Tests, $P>0,05$; Abb. 3). In einem zweiten Versuchsansatz haben wir über jeweils 10 Minuten die Anzahl aggressiver Arbeiterinnenkontakte gegenüber Jungköniginnen gezählt, welche (i) frei in einem Beobachtungskästchen herumliefen und (ii) dann von uns durch Einfrieren ( 2 Minuten bei $-82{ }^{\circ} \mathrm{C}$ ) getötet und auf die Brutwabe zurück gelegt wurden. Die Anzahl der Attacken auf die Königinnen hat sich durch das Töten und die damit einhergehende Unterbindung ihres auffallenden Verhaltens signifikant von 15 auf 0 (Mediane) verringert (Wilcoxon Test für Paardifferenzen, $P=0,008$ ). Kein Verhaltensunterschied konnte jedoch festgestellt werden, wenn die Arbeiterinnen mit toten Jungköniginnen oder mit toten Arbeiterinnen konfrontiert waren (Mann-Whitney Test, $P=1,0$; Abb. 4). Unsere Ergebnisse zeigen, dass Arbeiterinnen nicht durch volatile Duftstoffe aus größerer Entfernung zu den Jungköniginnen angelockt werden. Genauso wenig wird ihr aggressives Verhalten während den Exekutionen durch chemische Stoffe per se ausgelöst. Wir hypothetisieren, dass das auffallende Verhalten der virginellen Königinnen - und/oder dabei abgegebene Vibrationen bzw. Luftschallsignale - den Auslösemechanismus für die Arbeiterinnenattacken darstellen. Wir postulieren ferner, dass das Herumlaufen und schnelle Drehen der Jungkönigin als ehrliches Signal ihrer fitness dienen kann, da sie die Verfolgung durch die Arbeiterinnen für einige Zeit überleben müssen um schließlich als neue Königinnen akzeptiert zu werden.

\footnotetext{
Stachellose Biene / Melipona beecheii / Tötung von Jungköniginnen / Königinnenverhalten / Arbeiterinnenattacken
}

\section{REFERENCES}

Abdalla F.C., Jones G.R., Morgan E.D., Cruz-Landim C. da (2003) Comparative study of the cuticular hydrocarbon composition of Melipona bicolor Lepeletier, 1836 (Hymenoptera, Meliponini) workers and queens, Gen. Mol. Res. 2, 191-199.

Ayasse M., Paxton R., Tengö J. (2001) Mating behavior and chemical communication in the Hymenoptera, Annu. Rev. Entomol. 46, 31-78.

Bourke A.F.G., Ratnieks F.L.W. (1999) Kin conflict over caste determination in social Hymenoptera, Behav. Ecol. Sociobiol. 46, 287-297.

Cruz-Landim C. da, Abdalla F.C., Gracioli-Vitti L.F. (2006) Class III glands in the abdomen of Meliponini, Apidologie 37, 164-174.

Darchen R., Delage-Darchen B. (1975) Contribution à l'étude d'une abeille du Mexique, Melipona beecheii B. (Hymenoptère: Apide), Apidologie 6, 295-339.

Engels W., Imperatriz-Fonseca V.L. (1990) Caste development, reproductive strategies, and control of fertility in honey bees and stingless bees, in: Engels W. (Ed.), Social insects: an evolutionary approach to castes and reproduction, Springer, Berlin, Heidelberg, New York, pp. 167-230.

Faustino C.D., Silva-Matos E.V., Mateus S., Zucchi R. (2002) First record of emergency queen rearing in stingless bees (Hymenoptera, Apinae, Meliponini), Insectes Soc. 49, 111-113.

Gilley D.C. (2001) The behavior of honey bees (Apis mellifera ligustica) during queen duels, Ethology 107, 601-622.

Guerino A.C., Oliveira V.T.P. de (2002) Glândulas tegumentares do abdomen, in: Cruz-Landim C. da, Abdalla F.C. (Eds.), Glândulas exócrinas das abelhas, FUNPEC-Editora, Ribeirão Preto, São Paulo, pp. 111-126.

Hartfelder K., Makert G.R., Judice C.C., Pereira G.A.G., Santana W.C., Dallacqua R., Bitondi M.M.G. (2006) Physiological and genetic mechanisms underlying caste development, reproduction and division of labor in stingless bees, Apidologie 37, 144-163.

Howard R.W., Blomquist G.J. (1982) Chemical ecology and biochemistry of insect hydrocarbons, Annu. Rev. Entomol. 27, 149-172.

Howard R.W., Blomquist G.J. (2005) Ecological, behavioural, and biochemical aspects of insect hydrocarbons, Annu. Rev. Entomol. 50, 371-393.

Imperatriz-Fonseca V.L., Zucchi R. (1995) Virgin queens in stingless bees (Apidae, Meliponinae) colonies: a review, Apidologie 26, 231-244.

Jarau S., Twele R., Francke W., Aguilar I., van Veen J., Ayasse M. (2006) Queen signal of the stingless bee Melipona beecheii (Apidae, Meliponini), Proc. XV. IUSSI Congr., Washington, DC, p. 226. 
Kerr W.E. (1948) Estudos sôbre o gênero Melipona, An. Esc. Sup. Agricult. "Luiz de Queiroz" 5, 181276.

Kerr W.E. (1950) Genetic determination of castes in the genus Melipona, Genetics 35, 143-152.

Kerr W.E. (1969) Some aspects of the evolution of social bees (Apidae), Evol. Biol. 3, 119-175.

Kerr W.E. (1974) Sex determination in bees. III. Caste determination and genetic control in Melipona, Insectes Soc. 21, 357-368.

Kerr W.E., Nielsen R.A. (1966) Evidences that genetically determined Melipona queens can become workers, Genetics 54, 859-866.

Kerr W.E., Zucchi R., Nakadaira J.T., Butolo J.E. (1962) Reproduction in the social bees (Hymenoptera: Apidae), J. N.Y. Entomol. Soc. 70, 267-276.

Kerr W.E., Stort A.C., Montenegro M.J. (1966) Importância de alguns fatôres ambientais na determinação das castas no gênero Melipona, An. Acad. Bras. Ciênc. 38, 149-168.

Kerr W.E., Jungnickel H., Morgan E.D. (2004) Workers of the stingless bee Melipona scutellaris are more similar to males than to queens in their cuticular compounds, Apidologie 35, 611-618.

Kleinert A. de M.P. (2005) Colony strength and queen replacement in Melipona marginata (Apidae: Meliponini), Rev. Bras. Biol. 65, 469-476.

Kleinert A. de M.P., Imperatriz-Fonseca V.L. (1994) Virgin queens refuges in colonies of Melipona marginata (Apidae, Meliponinae), Rev. Bras. Biol. 54, 247-251.

Koedam D. (1995) Behavioural and physiological implications of queen dominance in stingless bees, Ph.D. thesis, Utrecht University, The Netherlands.

Koedam D. (1999) Production of queens, workers and males in the stingless bee Melipona favosa (Apidae: Meliponinae): patterns in time and space, Neth. J. Zool. 49, 289-302.

Koedam D., Aguilar Monge I., Sommeijer M.J. (1995) Social interactions of gynes and their longevity in queenright colonies of Melipona favosa (Apidae: Meliponinae), Neth. J. Zool. 45, 480-494.

Kucharski R., Maleszka J., Foret S., Maleszka R. (2008) Nutritional control of reproductive status in honeybees via DNA methylation, Science 319, 1827-1830.

Michener C.D. (1974) The social behavior of the bees: a comparative study, Belknap Press of Harvard University Press, Cambridge, Massachussets.

Monnin T. (2005) Chemical recognition of reproductive status in social insects, Ann. Zool. Fenn. 43, 515-530.

Moo-Valle H., Quezada-Euán J.J.Q., Wenseleers T. (2001) The effect of food reserves on the pro- duction of sexual offspring in the stingless bee Melipona beecheii (Apidae, Meliponini), Insectes Soc. 48, 398-403.

Moo-Valle H., Quezada-Euán J.J.Q., Canto-Martín J., Gonzalez-Acereto J.A. (2004) Caste ontogeny and the distribution of reproductive cells on the combs of Melipona beecheii (Apidae: Meliponini), Apidologie 35, 587-594.

Morais M.M., Nascimento F.S., Pereira R.A., Bego L.R. (2006) Colony internal conditions related to caste production in Melipona compressipes fasciculata (Apidae, Meliponini), Insectes Soc. 53, 265268.

Pflugfelder J., Koeniger N. (2003) Fight between virgin queens (Apis mellifera) is initiated by contact to the dorsal abdominal surface, Apidologie 34, 249-256.

Ratnieks F.L.W. (2001) Heirs and spares: caste conflict and excess queen production in Melipona bees, Behav. Ecol. Sociol. 50, 467-473.

Sakagami S.F. (1982) Stingless bees, in: Hermann H.R. (Ed.), Social insects, Vol. 3, Academic Press, New York, pp. 361-423.

Sakagami S.F., Oniki Y. (1963) Behavior studies of the stingless bees, with special reference to the oviposition process. I. Melipona compressipes manaosensis Schwarz, J. Fac. Sci. Hokkaido Univ. Ser. VI Zool. 15, 300-318.

Sakagami S.F., Montenegro M.J., Kerr W.E. (1965) Behavior studies of the stingless bees, with special reference to the oviposition process. V. Melipona quadrifasciata anthidioides Lepeletier, J. Fac. Sci. Hokkaido Univ. Ser. VI Zool. 15, 578-607.

Santos-Filho P. de S., Alves D. de A., Eterovic A., Imperatriz-Fonseca V.L., Kleinert A. de M.P. (2006) Numerical investment in sex and caste by stingless bees (Apidae: Meliponini): a comparative analysis, Apidologie 37, 207-221.

Silva D.L.N. da, Zucchi R., Kerr W.E. (1972) Biological and behavioural aspects of the reproduction in some species of Melipona (Hymenoptera, Apidae, Meliponinae), Anim. Behav. 20, 123-132.

Singer T.L. (1998) Roles of hydrocarbons in the recognition systems of insects, Am. Zool. 38, 394-405.

Sommeijer M.J., de Bruijn L.L.M., Meeuwsen F.J.A.J., Martens E.P. (2003a) Natural patterns of caste and sex allocation in the stingless bees Melipona favosa and $M$. trinitatis related to worker behaviour, Insectes Soc. 50, 38-44.

Sommeijer M.J., de Bruijn L.L.M., Meeuwsen F.J.A.J., Slaa E.J. (2003b) Reproductive behaviour of stingless bees: nest departures of non-accepted gynes and nuptial flights in Melipona favosa (Hymenoptera: Apidae, Meliponini), Entomol. Berichten 63, 7-13. 
Sommeijer M.J., de Bruijn L.L.M., Meeuwsen F.J.A.J. (2003c) Reproductive behaviour of stingless bees: solitary gynes of Melipona favosa (Hymenoptera: Apidae, Meliponini) can penetrate existing nests, Entomol. Ber. 63, 31-35.

Sramkova A., Schulz C., Twele R., Francke W., Ayasse M. (2008) Fertility signals in the bumblebee Bombus terrestris (Hymenoptera: Apidae), Naturwissenschaften 95, 515-522.

Tarpy D.R., Gilley D.C. (2004) Group decision making during queen production in colonies of highly eusocial bees, Apidologie 35, 207-216.

van Veen J.W. (2000) Cell provisioning and oviposition in Melipona beecheii (Apidae, Meliponinae), with a note on caste determination, Apidologie 31, 411-419. van Veen J.W., Sommeijer M.J., Aguilar Monge I. (1999) Behavioural development and abdomen inflation of gynes and newly mated queens of Melipona beecheii (Apidae, Meliponinae), Insectes Soc. 46, 361-365.

Wenseleers T., Ratnieks F.L.W., Billen J. (2003) Caste fate conflict in swarm-founding social Hymenoptera: an inclusive fitness analysis, J. Evol. Biol. 16, 647-658.

Wenseleers T., Hart A.G., Ratnieks F.L.W., QuezadaEuán J.J.G. (2004) Queen execution and caste conflict in the stingless bee Melipona beecheii, Ethology 110, 725-736.

Wilson E.O. (1971) The insect societies, The Belknap Press of Harvard University Press, Cambridge, Massachussets, London. 